\title{
Stagnation and unnaturally low interest rates: a simple critique of the amended New Consensus and the Sraffian supermultiplier alternative*
}

\author{
Franklin Serrano \\ Professor Associado, Instituto de Economia, Universidade Federal do Rio de Janeiro (IE-UFRJ), Brazil \\ Ricardo Summa \\ Professor Associado, Instituto de Economia, Universidade Federal do Rio de Janeiro (IE-UFRJ), Brazil \\ Vivian Garrido Moreira \\ Post-Doctoral Researcher, Programa de Pós-Graduação em Economia, Universidade Federal de Santa \\ Catarina (PPGE-UFSC), Florianópolis, Brazil
}

This paper argues that the amended versions (financial wedge and secular stagnation) of the simple pragmatic New Consensus model are as open to theoretical criticism as the original one was. The authors show that: (i) the real natural rate of interest is unlikely to be negative, (ii) it (inconsistently) depends on the Neoclassical investment function drawn at a position of full employment in a model in which the economy is demand-constrained, and (iii) both investment and full employment saving are induced by the trend of demand in the longer run and this challenges the usefulness of the notion of a natural or neutral rate of interest, which (iv) are also subject to the Sraffian capital critique. This is then contrasted with an alternative simple Sraffian supermultiplier model in which the interest rate and the financial wedge are distributive instead of allocative variables, and there is no natural rate of interest since in the longer run there is no trade-off between consumption and investment and also no full employment of labor. As the capital stock adjusts to demand, potential (capacity) saving will be determined by investment, and both investment and capacity saving increase when consumption increases. Finally, we briefly illustrate how this alternative model could begin to make sense of the recent relevant stylized facts.

Keywords: stagnation, Sraffian supermultiplier, New Consensus model

JEL codes: $E 11, E 21, E 22, E 40$

\section{INTRODUCTION}

The relative stagnation of growth in advanced countries since the Great Recession of 2008 has led to a debate about its underlying causes. The most salient stylized facts of

* This is an extensively revised version of our paper presented at the 1st International Workshop on Demand-Led Growth in Rio de Janeiro in July 2018. The authors would like to thank (but not implicate) André Lourenço, Atillio Trezzini, Sergio Levrero, Murray Milgate, and an anonymous referee for helpful comments on earlier drafts. The authors gratefully acknowledge financial support in the form of research grants from two Brazilian government agencies, namely CNPq (Ricardo Summa and Franklin Serrano) and CAPES (Vivian Garrido Moreira). 
this period are a combination of stagnant growth with low but relatively stable inflation and record low real interest rates in the advanced economies (Summers 2015; Yellen 2016).

Making sense of these stylized facts presents a challenge to the mainstream view, ultimately based on the simple pragmatic New Consensus - or 'three equation' - model. This model posits the existence of a unique real natural rate of interest, determined by the Neoclassical investment demand and full employment saving supply functions, that would make aggregate demand equal to the (factor-supply-determined) level of potential output. In this view, the natural rate of interest is an allocative variable (it clears the market for the demand and supply of the flow of new capital) and, most importantly, entails an inverse relation between consumption and investment (and usually also the full crowding-out of government spending) in the long run. Given short-run nominal price and wage rigidities, the task of the monetary authority is to set the actual interest rate to manage aggregate demand (and thus current output), and this policy interest rate should tend to the natural rate in order to close the output gap.

Some policy-oriented mainstream economists - such as Lawrence Summers, Olivier Blanchard, Paul Krugman, and Robert Hall - took the challenge and have amended the New Consensus model to explain the stagnant growth under very low interest rates, by using ideas such as the zero lower bound of nominal interest rates, combined with the financial wedge and/or negative levels of the natural real interest. These amended versions can be roughly organized into two broad types (although many authors combine elements of the two): (i) a shorter-run version that emphasizes financial frictions and disturbances causing changes in the financial wedge between the pure natural rate of interest and the actual full employment-rate ruling in the market; and (ii) a secular stagnation version that emphasizes changes in the long-run determinants of the natural rate of interest. Although they may lead to policy prescriptions that can be quite different from those that come from the original model (namely, unconventional monetary policies and fiscal expansion), these amended versions still retain the central Neoclassical notion of a unique full employment real natural rate of interest, while at the same time admitting that it may be quite difficult for policy interest rates to adjust to it.

The purpose of this paper is twofold. First, to highlight the main theoretical shortcomings of the New Consensus model and its amendments, especially in regard to the concept of the natural rate of interest. ${ }^{1}$ Second, to illustrate the radically different implications of following an alternative route based on the Sraffian surplus approach. In order to achieve its purpose, the paper sets out to provide the simplest analytical framework in which these different points of view, on how to explain some of these stylized facts, can be compared and contrasted.

For the critical task we shall build upon some results from the Sraffian literature (Garegnani 1979; Petri 2004), and in particular the new critique on the 'position' of the Neoclassical investment function put forward by Petri $(2013 ; 2015)$, of which some interesting implications will be derived, if we follow through the inevitable process of adjustment of the capital stock to the actual trend of demand (Garrido Moreira and Serrano 2018). For the more constructive tasks, we take an alternative route, getting rid of all the Marginalist (Neoclassical) elements and considering a simple version of the Sraffian supermultiplier model (Serrano 1995) in which, in the longer run, the expansion of the autonomous components of demand - which may depend on the real interest rate - and changes in the marginal propensity to consume drives not only the

1. Our critique here is made on purely theoretical grounds. See Levrero (2019) for a complementary critique of the empirically estimated natural rates of interest. 
current level of output and the actual degree of capacity utilization but also the evolution of the capital stock and productive capacity through a flexible accelerator mechanism.

The structure of the paper is as follows. The pragmatic New Consensus model, together with some of its recent proposed amendments will be presented in Section 2. In Section 3, we present the first part of our critique of the concept of the natural rate of interest that is particularly damaging for the secular stagnation version of the amended New Consensus. In Section 4, we will present further criticism of the notion of the natural or neutral rate of interest, which applies equally to the traditional New Consensus and both its secular stagnation and financial wedge amended versions. Section 5 then presents our alternative IS curve, based on a simple alternative Sraffian supermultiplier model and its main results. Brief remarks on how the latter kind of model could make sense of some of the relevant recent stylized facts are made in the final Section 6.

\section{THE NATURAL RATE OF INTEREST AND THE (AMENDED) NEW CONSENSUS}

\subsection{The simple New Consensus model}

We start by presenting how the real full employment natural rate of interest is determined in the well-known simplest version of the New Consensus model, as the price that brings into equality the demand for investment and the supply of full employment saving. ${ }^{2}$

This model, usually referred to as the 'three equations model' (Carlin and Soskice 2005; Blanchard 2016), consists of an accelerationist Phillips curve, ${ }^{3}$ an IS curve, and a reaction function of the central bank, which sets the nominal interest rate. The full employment (or potential) output $\left(Y^{*}\right)$ is seen as determined by the supply of factors and their efficiency, and is not influenced by aggregate demand (Solow 1997, p. 230).

The level of current output, $Y$, is determined by aggregate demand ${ }^{4}$ because of some assumed (and admittedly never satisfactorily explained) nominal rigidities in prices and wages. Aggregate demand consists of household spending, business investment, and government expenditures. Household consumption is partly induced by disposable

2. This simple model reflects the approach to modeling aggregate macroeconomic functions in an 'opportunistic' way, that is, 'whatever works empirically' (Solow 1997, p. 231), which must be 'useful and extensively used in policy analysis, where contact with reality is a necessity' (Blinder 1997, p. 240). This model 'is now pervasive in policy research projects at universities and central banks around the world' (Taylor 2000, p. 90). For a recent version of this simple aggregate model, see Blanchard (2016) and for a methodological defense of using 'toy models,' see Blanchard (2018).

3. The related discussion about the low and stable recent inflation and particularly the anchored Phillips curve, which has been proposed by proponents of the amended New Consensus and our alternative conflict augmented Phillips curve, can be found in Serrano (2019) and Summa and Braga (2019). Along similar lines, see Palley (2018) and Stirati and Meloni (2018). 4. For maximum simplicity, we assume all magnitudes to be gross of depreciation. Output is assumed to be produced by homogeneous labor and a single circulating capital good which is also the single consumption good. There are an indefinitely large number of alternative methods of production available that are assumed to be ordered in a traditional Neoclassical production function and the initial endowments of inelastically supplied labor and the capital stock of the business sector are exogenously given. 
income (taxed at the rate $t$ ) with a given marginal propensity to consume, $c$. There are also some interest-sensitive autonomous household expenditures (consumption and residential investment, ${ }^{5}$ written as $A=A_{0}-\alpha . r$, and comprising autonomous demand from both capitalists and workers with access to credit) which are negatively related to the level of the real rate of interest $(r)$. Government spending $(G)$ is exogenous and does not affect potential output. Business investment that creates capacity for the business sector, $\left(I=I_{0}-\beta . r\right)$, is also interest-elastic, for the usual Neoclassical reasons (factor substitution). Equation (1) shows the IS curve, whose slope reflects the real interest-rate sensitivity of the various types of expenditures and the size of the usual Keynesian multiplier.

$$
Y=\frac{G+A_{0}-\alpha \cdot \mathrm{r}+I_{0}-\beta . r}{1-c(1-t)}
$$

From equation (1) it can be easily seen that there exists one level of real interest rate that corresponds to a level of output equal to the exogenously given full employment output $\left(Y^{*}\right)$. Formally, the natural rate of interest is given by equating the IS curve to the level of potential output and solving for $r$, as: ${ }^{6}$

$$
r_{n}=\frac{I_{0}-\left[Y^{*}-\mathrm{c}(1-\mathrm{t}) Y^{*}-A_{0}-G\right]}{(\alpha+\beta)} .
$$

Simply by subtracting consumption from both aggregate demand and potential output, we see that the real natural rate of interest will also be the one that equilibrates investment and full employment saving.

Given the assumption of interest-elastic (business) investment $(\beta>0)$, if actual output is assumed to tend towards the exogenous full employment level of output, then there is in the long run an inverse relation between consumption and investment and the full crowding-out of government expenditures.

\subsection{Amending the New Consensus model: the 'financial wedge' and 'secular stagnation'}

Some mainstream policy-oriented economists who use variants of the simple New Consensus consider that the recent stylized facts of growth stagnation with very low interest rates are caused by a marked slowdown in the expansion of aggregate demand. We may roughly divide them as broadly representing two distinct views: (i) the 'financial wedge' view, which implies that the stagnation is basically a long-lasting after-effect of the global financial crisis of 2008; and (ii) the 'secular stagnation' view, which refers to

5. For simplicity and convenience we will lump household (residential) investment, also assumed to be interest sensitive, together with autonomous consumption as the former by assumption does not increase the capital stock of the business sector and the potential output of the economy.

6. The term in square brackets in the numerator is the level of full employment saving when the real rate of interest $r$ is equal to zero. Note that only when the level of (business) investment related to a zero real rate of interest $-I_{0}$ - is greater than full employment saving at this same zero level of the real interest rate, full employment saving (the supply of new capital) will be scarce and the natural rate of interest $r_{n}$ is strictly positive. 
more structural elements and implies a more permanent trend of demand stagnation. In both cases, the stagnation is a result of more or less permanent negative demand shocks followed by a difficulty in restoring aggregate demand and current output to its full employment level due to the so-called 'zero' lower bound on nominal interest rates.

The main arguments of the first group - composed of Hall (2013), Bernanke (2015), Borio (2017), and Cabbalero et al. (2017), among many others - point to the negative effects on demand of a much-increased 'financial wedge' between policy interest rates set by the central bank and the interest rates that are actually relevant to spending on investment and consumption (and housing investment), and also to the increased marginal propensity to save due to the deleveraging of both the household and business sectors.

The financial wedge $\left(f_{i}\right)$ of business investment would depend on: (i) the term structure of interest rates on safe public debt; (ii) the spread due to lenders' risk between safe public debt rates and lending rates even to prime (triple-A-rated) corporate borrowers; and (iii) the additional profit margins required to compensate the risk and trouble' of investing in illiquid productive as opposed to liquid financial assets (and borrower's risk) which would be expressed in the 'equity premium' between stocks and bonds. The financial wedge $\left(f_{a}\right)$ of credit-financed autonomous consumption (and residential investment) would include the first two elements mentioned above, with the second being related to the specific spreads for the household credit markets (Hall 2013).

With the inclusion of the financial wedge variables, the investment function is rewritten as $I=I_{0}-\beta\left(f_{i}+r\right)$ and the autonomous component of the consumption function as $A=A_{0}-\alpha\left(f_{a}+r\right)$. This modifies expression (2) for $r_{n}$, which we now call the neutral rate of interest $r^{*}$, which is the real level of the policy rate of interest that equates aggregate demand with the given level of full employment output:

$$
r^{*}=\frac{\left(I_{0}-\left[Y^{*}-c(1-t) Y^{*}-A_{0}-G\right]\right)-\left(\alpha f_{a}+\beta f_{i}\right)}{(\alpha+\beta)} .
$$

In equation (3) we can easily see how the shifts in the investment and consumption functions caused by increases in the elements of the financial wedge will reduce the level of the real neutral rate of interest. In fact the real neutral rate $r^{*}$ becomes equal to the level of the real natural interest rate $r_{n}$ minus a weighted average of the financial wedge variables (spreads) $f$, having the relative size of the interest elasticities of investment and consumption as weights:

$$
r^{*}=r_{n}-f=r_{n}-\frac{\left(\alpha f_{a}+\beta f_{i}\right)}{(\alpha+\beta)} .
$$

In equation (3) the deleveraging of the household sector can be treated as a fall in aggregate marginal propensity to consume $c$, which reduces the neutral real rate of interest. Shifts in distribution from wages to profits (due to rising equity premiums or a number of other causes mentioned in the literature) would also have the same effect of decreasing $c, r_{n}$, and $r^{*}$.

The second view, led by Summers (2015), sees the slowdown in aggregate demand as adverse shifts in the business investment function due to low growth of productivity, the labor force, and falling relative prices of capital goods (and/or capital-saving technical change), together with increases in the aggregate marginal propensity to save due mainly 


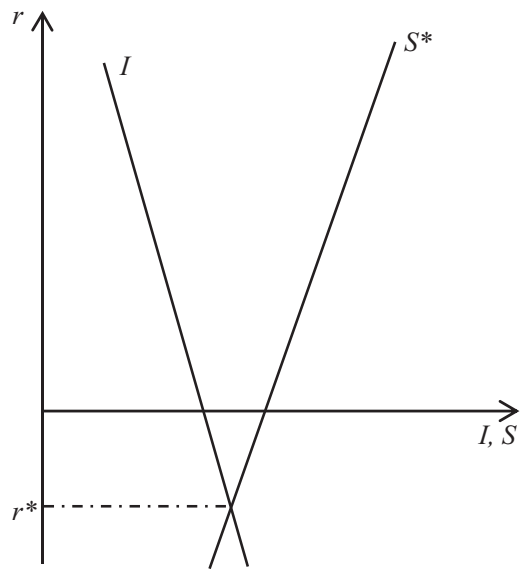

(a) Secular stagnation

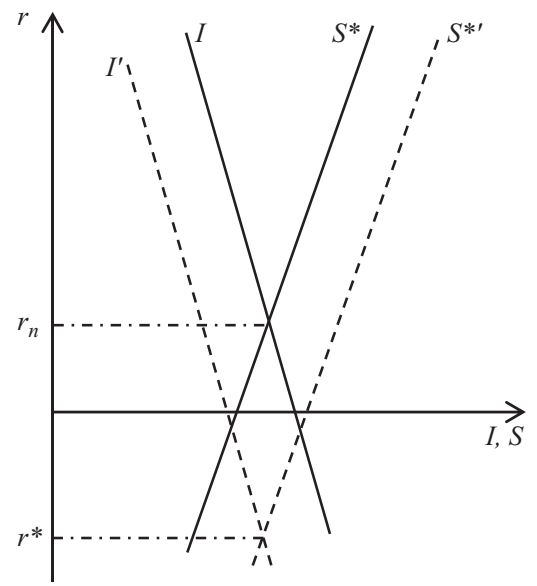

(b) Financial wedge

\section{Figure 1 Zero lower bound}

to rising income inequality. This is represented by a large shift of the investment function to the left (a fall in $I_{0}$ ) that entails a lower real natural interest rate.

Different authors emphasize different combination of the many arguments put forward by the two views, but what matters to us is that all of them either directly reduce the traditional natural rate of interest (decreased investment demand and higher marginal propensity to save) or the neutral real policy rate. Note also that if these aggregate demand adverse shocks are large enough, the natural (as proponents of secular stagnation tend to argue) or just the neutral real policy rate (as emphasized by some who follow the financial wedge view) may become quite negative. These two cases are illustrated in Figure 1.

\subsection{The zero lower bound}

In the New Consensus model, reductions in aggregate demand could be easily compensated by the action of the central bank, which, by setting lower interest rates, would stimulate aggregate demand and thus restore output to its full employment level. But if the negative shocks to demand are large enough it may be impossible for the central bank to achieve the real neutral interest rate by reductions in the policy nominal interest rate, since the nominal rate of interest set by the monetary authority has a lower bound at zero. $^{7}$ If the policy nominal interest rate is at the zero bound, the real policy interest rate is negative and equal to minus the rate of inflation when inflation is positive - the case discussed in this literature. ${ }^{8}$

7. In reality, in a few countries nominal policy rates have turned slightly negative recently, but it is not easy to imagine that nominal rates can be too negative without triggering large changes in the whole financial system, so that there is some limit. But let us not get into that, and assume, for our limited purposes, that the lower limit is actually zero.

8. If the nominal policy interest rate cannot be negative and the fact the nominal neutral policy interest rate is equal to the real neutral interest rate plus the rate of inflation $\left(i_{n}=r^{*}+p\right)$, there are three cases in which interest-rate policy cannot bring the economy to the full 
The proponents of the amended New Consensus model assume that the negative demand shocks have been sufficiently large as to require a negative nominal neutral policy interest rate. Although most authors are not very clear about this, note that in this case the zero bound can only be binding if not only the neutral rate is negative but also its negative value is greater than the positive rate of inflation $\left(r^{*}=r_{n}-f<-p\right) .^{9}$

\section{THE NATURAL RATE OF INTEREST AND SOME PROBLEMS WITH THE SECULAR STAGNATION STORY}

\subsection{Two difficulties with the notion of a negative real natural rate of interest}

The notion of a single full employment level of the real rate of interest is ultimately based on the traditional interest-elastic Neoclassical investment function, derived from the principle of factor substitution between capital and labor. In order to focus on this connection, in this section we provisionally assume away the financial wedge elements acting on business investment $\left(f_{i}=0\right)$ and autonomous consumption $\left(f_{a}=0\right)$, just in order to concentrate on the frictionless perfectly competitive case. Starting also with the further assumption that consumption is not interest-elastic at all $(\alpha=0)$, we can focus on a first difficulty, which curiously does not seem to have attracted much attention in the amended New Consensus literature, concerning the $a$ priori implausibility of the notion of a negative real natural rate of interest, starting from the usual Neoclassical principles. From these basic principles we know that the demand for capital (its marginal product curve) would shift to the right as long as more labor can be hired, if real wages are assumed to be flexible. When labor employment reaches its limit, and only then, the marginal productivity of capital begins to fall, and only reductions in the real rate of interest may allow firms to profit from using more capital with that given amount of labor.

The idea of the negative real natural rate of interest proposed by the amended New Consensus secular stagnation view (Summers 2015) requires that, as the stock of capital expands and its marginal product keeps falling, there would be a point at which the marginal product of capital falls to zero, a point that may only be reached at a zero real interest rate. Beyond that point, the marginal product of capital would turn negative and firms would not want to use more capital, even if the real interest rate also turned negative, because equipped with more capital the fully employed workers would actually produce less, and the level of potential output would in fact decline. ${ }^{10}$ This means that, under those conditions, there is an upper bound to the size of the desired stock of capital given the level of the fully employed labor force $K_{\max }$ at a zero real rate of

employment position, under the assumptions of the New Consensus model. The first is when the real neutral interest rate is negative and the economy is under a process of deflation. The second is when there is deflation and prices are falling at a rate that is in absolute terms greater than the level of the neutral real rate of interest (which can be positive). The third (discussed more often in this literature) is when inflation is zero or positive but the real neutral rate of interest is itself negative and in absolute terms greater than the rate of inflation.

9. Krugman (2015) and Summers (2015) assume a situation of more or less permanent negative real natural rates, but neither of them refers explicitly to these negative natural real rates as being lower than minus the rate of inflation.

10. Note that if the so-called elasticity of substitution is assumed to be equal to one (as in a Cobb-Douglas production function) the marginal product of capital would actually never fall to zero, and thus the lower bound to the real natural rate of interest will be always strictly 
interest, and this accordingly fixes a corresponding maximum level of gross investment in the long run, $I_{\max }=d . K_{\max }$ (where $d$ is the replacement coefficient, equal to one under our simplifying assumption that there is only circulating capital). Firms would, in the long run, seem to have no incentive to invest more than this amount at any rate of interest equal to or below zero.

In this situation of capital saturation, investment would not respond even to negative real interest rates. And if full employment saving is interest-inelastic and greater than this maximum level of investment, a natural real rate of interest, instead of being negative, simply does not exist (see Figure 2a).

Palley (2016) argues that even if the central bank somehow managed to produce very negative real interest rates (either through inflation or by sufficiently negative nominal policy rates), investors would prefer to buy existing financial assets rather than new capital goods, as the former would have non-negative nominal rates of return. This may well also be the case, but our point is more general: even with very negative real policy interest rates firms would probably not buy new capital goods if those would actually reduce their productive capacity.

We may now briefly reintroduce the assumption that consumption may be interestelastic $(\alpha>0)$ to look at the problem from the full employment saving side (but still leaving out the financial wedge variables), and show another reason why a negative real natural rate would be implausible from a strictly Neoclassical point of view. Even abstracting from the possibly complex individual and collective income effects on the choice between consumption and saving of Neoclassical consumers, it would seem reasonable to expect, if there is a generalized preference for present over future consumption, that full employment saving would fall to zero as the real interest rate available to savers fell towards zero. In fact, under the usual 'consumption smoothing' assumptions, with a zero real return on saving there seems to be no point in sacrificing present for the sake of future consumption in a stationary economy. That means that the full employment saving function would probably tend to become horizontal ( $\alpha$ would tend to infinity) at very low near-zero positive real interest rates, and as net investment would, as we have seen above, fall to zero, consumers would consume the whole full employment level of net output (see Figure 2b). ${ }^{11}$

The above discussion allows us to see clearly that the concept of a negative real natural rate of interest has rather weak theoretical foundations. Yet it is in fact one of the key assumptions of the new secular stagnation literature, which argues that the economy is trapped in the zero bound of nominal interest rates because the real natural rate is (sufficiently) negative. This appears difficult to sustain at a theoretical level.

For the proponents of the financial wedge approach, who do not need to posit that the natural real rate of interest itself is necessarily negative, the minimum value that the (average) financial wedge must have in order for the economy to be trapped in

positive (even if full employment saving is interest-inelastic). For criticism of the idea of a negative natural rate of interest, see Pagano and Sbracia (2014), Di Bucchianico (2019), and Garrido Moreira and Serrano (2018).

11. It is therefore hardly surprising that in this literature Neoclasicals have had to appeal to the extremely unrealistic assumption that the levels of full employment output in the future are going to be permanently lower than in the present in order to avoid full employment saving from falling to zero, preventing the real natural rate of interest from turning negative, when the real rate of interest falls to zero under 'consumption smoothing.' See Di Bucchianico's $(2018 ; 2019)$ critique. 


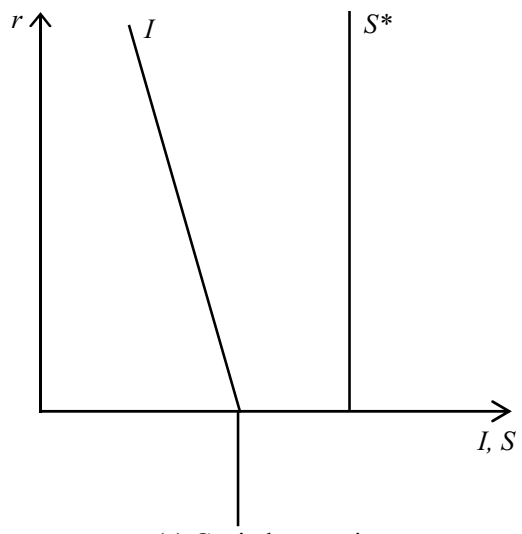

(a) Capital saturation

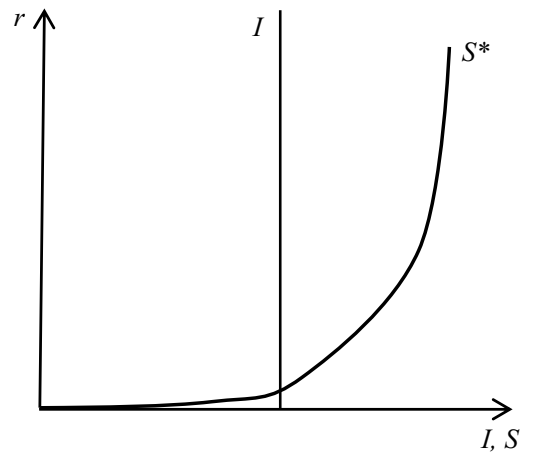

(b) Lower limit to full employment saving is zero

Figure 2 A negative real natural rate of interest is unlikely

the zero bound of the nominal policy interest rate must be larger than the (admittedly low but still positive) rate of inflation plus the (positive) real natural rate of interest $\left(f>r_{n}+p\right)$. We do not find in the literature any reason explaining why the financial wedge would be sufficient large. In fact, it is merely because in reality the monetary policy does not seem to bring the economy to the level of potential output that the financial wedge is simply deduced to be sufficiently large for the neutral rate of interest $r^{*}$ to be negative.

\subsection{A problem with the 'position' of the Neoclassical investment function: investment depends on actual instead of full employment levels of output}

Even if we discard the notion of a negative natural rate of interest, a single positive natural full employment rate of interest itself has its own shortcomings. Petri (2013; 2015) pointed out that the position of the demand curve for capital and investment must ultimately depend on the actual level of labor that firms will employ with it.

In fact, if labor happens not to be fully employed, the demand curve for capital and investment will be infinitely elastic at any given level of the real rate of interest below the average product of capital and in practice $\beta$ becomes infinite. Decreasing marginal returns to capital and thus the interest-elasticity of the demand for investment (capital) can only happen if the amount of the other factors in use is given.

On the other hand, if we assume that we are in the context of an economy in which the rate of interest is higher than the natural or neutral rates, and nominal rigidites make actual short-run levels of output and labor employment be determined by effective demand, we cannot really use the traditional Neoclassical investment function, which takes the full employment level of output as an argument.

Thus, if firms know and thus expect that output and employment will vary with the level of effective demand, the desired stock of capital and hence the level of investment will necessarily depend to some extent on the (expected and) actual levels of employment and output, instead of on the full employment level of output. If, for instance, the actual level of output and employment falls below the initial full employment level of output, this 


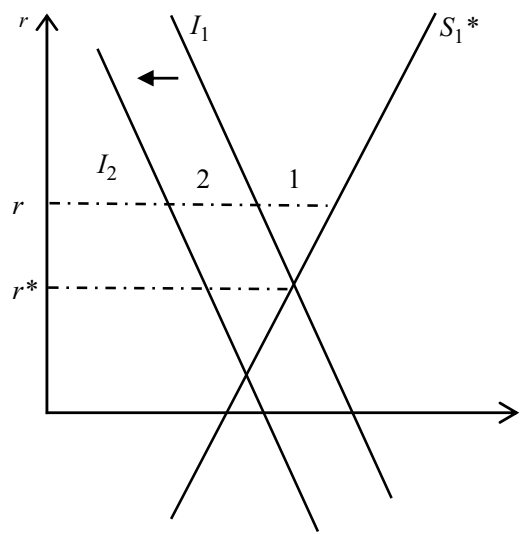

(a) The actual investment function shifts

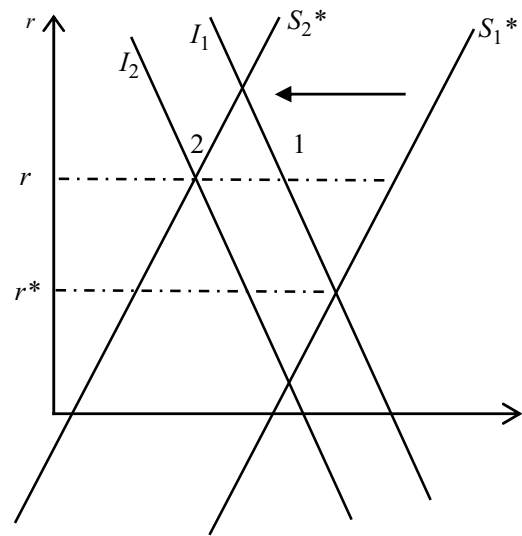

(b) Later, full employment saving also changes

\section{Figure 3 The endogeneity of full employment saving}

will tend to shift the whole actual-demand curve for capital and investment to the left, changing (lowering) the real natural rate of interest (see Figure 3a).

This simple yet fundamental criticism by Petri concerning the position of the investment function is particularly damaging for the 'secular stagnation' 12 view in an economy where actual output and employment is determined by demand in the short run. The Petri critique implies that there is simply no reason why a reduction in the growth of the size of the labor force and/or a lower rate of growth of labor productivity - factors that surely would shift the Neoclassical full employment demand for investment to the left, as labor is becoming relatively more scarce, dragging down the marginal product of capital - should have any negative effect on the actual levels of investment in an economy in which the actual level of employment is constrained by the effective demand for the product and there are unemployed workers. If labor in fact is not scarce, there is also no reason why an increase in the size of the labor force or its productivity, which would in practice only increase the level of unemployment, should be seen as something that increases the actual demand for investment.

Thus, of the three elements listed by Summers as being responsible for a leftward shift in the demand for investment, namely a lower increase in the size of the labor supply, lower rates of growth of productivity, and a capital-saving bias in technical change, only the latter may have a negative effect of the actual (as opposed to the full employment) investment function. So it is simply not possible to explain a presumed secular stagnation of demand by arguing that investment is low because of slow technical change and labor force growth, as these elements have no effect on investment unless we arbitrarily assume that firms expect the economy to be always at full employment in the near future when deciding how much to invest, even when these same firms know that this is not true when determining their own levels of current output.

12. See Garrido Moreira and Serrano (2018) for a detailed critique of both the Old (Hansen) and the New (Summers) theses of secular stagnation in their relation to the theories of growth. 


\section{FURTHER PROBLEMS WITH THE POSITION AND THE SLOPE OF THE INVESTMENT FUNCTION AND THEIR IMPLICATIONS FOR THE NEW CONSENSUS AND ITS AMENDED VERSIONS}

\subsection{The adjustment of the capital stock to demand and the endogeneity of full employment saving}

From the Petri $(2013 ; 2015)$ critique it follows that the actual demand for investment will shift to the left whenever the actual real rate of interest is above the natural rate of interest and aggregate demand and output fall below full employment. As the size of the desired capital stock depends on the expected levels of demand and output that in turn respond to persistent changes in the actual levels of demand and output, the level of investment will then be further reduced. But this reduction of induced investment will then lead to more reductions in aggregate demand both directly and through the decrease in induced consumption through the usual multiplier effect. This will set in motion a multiplier accelerator process that in principle could be unstable.

In our framework, in which there is an autonomous demand component (autonomous consumption and housing investment) that does not generate capacity for the business sector, we could make this capital stock adjustment process at a given real interest rate dynamically stable. This could be done by adding the assumption that expected demand reacts gradually to actual demand (a flexible accelerator mechanism).

But even in this stable case, the size of the capital stock will tend to adjust itself to the lower persistent level of demand at an interest rate above the original natural rate, and this capital stock will certainly be considerably smaller than the initial level of the capital stock. But if and when that happens, the level of full employment output has been permanently reduced by a fall in aggregate demand, as the same labor force will have a permanently lower stock of capital to work with.

In this situation, the causality between the rate of interest and the capital stock is reversed. Now it is the actual real rate of interest that is a determinant of the size of the capital stock, instead of the size of the initial capital stock being one of the determinants (through the full employment investment function) of the natural rate of interest.

The upshot of all this is that, unless deviations from full employment are so small and short-lived that they have no effect on the expected levels of output and employment, the position of the demand for investment will shift to the left with persistent changes in the actual level of output. And these inevitable accelerator multiplier effects will act both on aggregate demand and later on the size of the capital stock, and will occur for any given level of the actual real rate of interest.

But, as full employment saving depends directly on the size of potential output, the full employment level of saving will also change endogenously.

Thus, even assuming that the capital stock adjustment process is dynamically stable, a real rate of interest persistently above the natural rate will tend to lower the levels of effective demand and output and this will not only shift the position of the investment function to the left but will also, through its capacity effects, shift the level of the full employment saving function to the left (Figure 3b) as potential output is reduced. At that given real rate of interest, investment will not only determine aggregate actual saving but also, in a longer run, as the capital stock adjusts to demand, the level of full employment saving.

Even taking into account that investment necessarily depends on actual demand, a single real natural rate of interest corresponding to the initial stock of capital already in existence may still exist. And this natural rate will be exactly the same as the one 
calculated when investment is always determined by the full employment level of output. This follows from the fact that the consumption function is the same (and government spending and taxation are also the same), and so is both the initial capital stock and the labor endowment. Thus, potential output and also full employment saving will necessarily be the same. This real natural rate of interest, however, is not of much use unless we further assume that deviations from it are sufficiently small and short-lived in order not to change persistently the levels of investment and the desired stock of capital. Therefore, interest rates persistently above (below) the (initial) natural rate will tend to lead to permanently lower (higher) levels of both actual output and the capital stock and thus a higher (lower) natural rate of interest. In both cases, potential output and the natural rate of interest will change.

This criticism applies equally to the secular stagnation and financial wedge amendments and to the original New Consensus model. Adding the financial wedge variables will change the value of the relevant policy neutral interest rate but cannot change the fact that both investment and full employment saving are endogenous in an economy where actual output and employment can move substantially away from full employment in the short run.

\subsection{Heterogeneous capital and the Sraffian critique}

Besides the serious inconsistencies discussed above about the position of the Neoclassical investment demand function, we must not forget that there are also the wellknown serious problems with its slope. The slope of the full employment neoclassical investment function derives from the traditional principle of substitution between labor and capital (Garegnani 1979; Petri 2004) and many other Sraffians have shown that in a more realistic context of heterogenous capital caused by the complex dependence of relatively long-run supply prices on changes in distributive variables, there is no reason to rule out phenomena such as 'reverse capital deepening' (with or without 'reswitching'). Such phenomena would imply positively sloped segments of the demand for capital and investment. After decades of controversy it is an established result that a long-period inverse relation between investment and the real rate of interest is not a valid general result but is guaranteed only under the unrealistic assumption of homogenous capital and cannot be generalized.

There is also a large amount of empirical evidence showing that, in reality, business investment hardly responds directly to lower interest rates, evidence that has a long history (as reported by Garegnani 1979). Nowadays, such evidence is becoming more difficult to ignore, given the large reductions in interest rates in the advanced economies since 2010 and the obvious lack of reaction of business investment.

Again, this criticism applies to both the secular stagnation and financial wedge versions since if investment is not regularly and sufficiently elastic to the real rate of interest, the very concept of a natural rate of interest and the ability of the interest rate to regulate the level of investment relative to potential saving ceases to be valid.

As the Sraffian capital theoretic critique undermines the general validity of the principle of substitution between capital and labor, and investment is not a regular inverse function of the rate of interest, for these same reasons, it is equally unlikely that the level of employment per unit of output will be regularly elastic to real wages. Accordingly, there is also no good reason to assume that a given capital stock will always be able to employ any number of workers, and thus structural unemployment can result even when the capital stock is fully utilized (Garegnani 1979). 


\section{THE SRAFFIAN SUPERMULTIPLIER ALTERNATIVE}

\subsection{Equally simple but different assumptions}

We thus have no good theoretical (given the Sraffian capital theoretic critique) or empirical reason to keep the assumption that $\beta>0$ and will drop it from now on and treat the technical normal capital-output ratio as exogenously given. When we do this, we discard even the possible limited effect of the interest rate on investment through the value of the technical normal capital-output ratio. We thus replace the Neoclassical investment function by a very simple induced investment function in which the investment share in current output (the propensity to invest) depends on the expected trend growth of demand $g^{e}$, the capital replacement coefficient $d$ (equal to one in our simple circulating capital model) and the normal capital-output ratio, $v$ :

$$
I=v\left(d+g^{e}\right) Y .
$$

The expected trend rate of growth of actual demand and output $g^{e}$ is more reasonably formalized as a flexible accelerator (adaptive expectations) mechanism, where the expected trend increase in demand is gradually $(x<1)$ updated in light of past realized rates of growth of actual demand and output $(g)$ :

$$
g^{e}=x g_{-1}+(1-x) g_{-1}^{e} .
$$

Having discarded the Neoclassical investment function, we can get rid of factor substitution altogether and explicitly assume that the single production method in use combines labor and capital in fixed proportions, and potential output is now given by:

$$
Y^{*}=\min (K / v, N / 1),
$$

where 1 and $v$ are respectively the labor and capital input coefficient per unit of output, $K$ is the capital stock and $N$ is the size of the labor force. We also realistically assume that labor is relatively more abundant than capital and thus the full employment level of output, $N / 1$, is much greater than the full capacity level of output, $K / \nu .{ }^{13}$ Potential output is thus determined by the size of the capital stock and there is some structural unemployment.

We shall also now revert to the previous assumption that the level of autonomous consumption (and residential investment) is somewhat interest-elastic $(\alpha>0)$. In this alternative setting, the interest rate may affect the level of effective demand and output by two different routes. The first is directly through its impact on autonomous consumption (and housing investment). The second is indirect, through the (more realistic) distributive rather than allocative role of the interest rate. In fact, Sraffa and some of his followers pointed out that the real rate of interest seems both, in terms of financial costs and opportunity costs, for the firms may set a floor for the normal rate of profits

13. The adjustment of the size of the labor force to employment opportunities, the latter determined by the levels of effective demand and labor productivity, operates through very slow endogenous changes in both the size of the labor force itself (national or international migration, changes in participation rates, numbers of hours worked and in the size of the informal sector (Garegnani 1990), and of labor productivity (endogenous technical progress embodied in the new capital goods). 
(the profit rate at normal capacity utilization) that affects the profit share. Therefore, a higher rate of interest, $r$, may increase the profit share and lower the wage share. And that lower wage share will decrease the economy's marginal propensity to consume, the multiplier, and the equilibrium level of output.

Our financial wedge variables may now also be reintroduced. We shall keep the assumption that autonomous consumption (and residential investment) depends on both the rate of interest and the relevant financial wedge, $f_{a}$, which measures how much the actual rates of interest paid by households are above the policy determined interest rate, $r$.

We further assume that all consumption of capitalists is autonomous and included in $A$ and workers consume a fraction, $c_{w}$, of their wages (the wage share denoted by $w$ ), such that the marginal propensity to consume can be rewritten as $c(1-t)=c_{w} \cdot w(1-t)$.

The other financial wedge variable, $f_{i}$, reflecting the relevant conditions for firms, while no longer relevant to determine the amount of capacity generating private investment (since $\beta$ is now zero), may still be relevant but for the determination of income distribution.

Indeed, we shall now take $f_{i}$ to mean the excess of the required rate of profit at normal capacity utilization over the policy-determined interest rate. This means that the normal rate of profit must be equal to:

$$
(1-w) / v=r+f_{i}
$$

which gives us the wage share as: ${ }^{14}$

$$
w=1-v\left(r+f_{i}\right) .
$$

This extends Pivetti's (1991) monetary explanation of distribution to a monetary and financial explanation of distribution, as the financial wedge spreads that firms face may be passed on to profit margins and increase prices in relation to money wages.

With these modifications, we now have an alternative model, a simple Sraffian supermultiplier in which long-period effective demand is determined by:

$$
Y=\frac{A_{0}-\alpha\left(r+f_{a}\right)+G}{1-\left(1-v\left(r+f_{i}\right)(1-t)-v\left(d+g^{e}\right)\right.},
$$

and in which, assuming the model is dynamically stable, ${ }^{15}$ capacity will tend to adjust to demand in a longer run towards a fully adjusted position that slowly gravitates towards:

$$
\frac{K}{v}=Y^{*}=Y=\frac{A_{0}-\alpha\left(r+f_{a}\right)+G}{1-\left(1-v\left(r+f_{i}\right)(1-t)\right)-v(d+z)},
$$

14. Note that we assume, following the Sraffian view (Freitas and Serrano 2015), that competition from other firms and potential new entrants forces prices to gravitate towards normal prices of production, prices that include the normal rate of profit, even when the actual average level of capacity utilization may be quite different from the normal or desired level. This makes the profit margins and thus the profit share a function of the normal rate of profits and its determinants. 15. Basically that $x$ in equation (6) is sufficiently small. For the formal analysis of the dynamic stability conditions of a similar Sraffian supermultiplier model, see Serrano et al. (2019). 
where $z$ is the rate of growth of the autonomous components of demand (a weighted average between the rate of growth of government spending and autonomous consumption). In this model the economy will, in a longer run, tend to grow at the rate $z$ at which total autonomous demand is expanding. Through the supermultiplier process the productive capacity and the capital stock will through induced investment allow the actual degree of capacity utilization to gravitate towards the normal or planned degree. ${ }^{16}$

We have arrived at an alternative IS curve relating aggregate demand (and current output) with the real interest rate (equations (10) and (11)), but in which the effects of the interest rate work through residential investment and autonomous consumption and not directly on productive (which generate productive capacity) investment. ${ }^{17}$

Note, however, that this kind of relation between real interest rate and aggregate demand and output can be quite unstable, since it depends on the capacity and willingness of households to borrow and on the banks (and financial system) to lend to creditworthy clients. Autonomous consumption financed by credit depends on the relation between households' indebtedness and the evolution of disposable income. High levels of indebtedness in relation to disposable income can reduce the pace of borrowing (or even stop it altogether). In the supermultiplier model, changes in other autonomous spending (like a slowdown in the growth of government and/or exports) can deteriorate households' indebtedness conditions (Pariboni 2016). Also, situations of financial stress can lead to a (at least temporary) credit crunch. Moreover, a process of household deleveraging can also change the relation between interest rates and autonomous spending. ${ }^{18}$ One simple way to introduce a deleveraging process in our model is to consider that the autonomous consumption of many workers not only is reduced but may in fact turn negative after a financial crisis (as a positive level of credit-financed autonomous consumption corresponds to an increase in net debt) since they are saving and transferring income to banks, which owners (and shareholders) have a much smaller marginal propensity to consume (assumed to be zero here for simplicity).

\subsection{The adjustment of capacity to demand and the relation between consumption, investment, and capacity saving}

Our simple Sraffian supermultiplier thus gives us an alternative IS curve, which under the simple assumptions here is in fact negatively sloped, because of the effects of policy interest rates and financial wedge variables on credit-financed autonomous consumption and on the wage share and induced consumption. However, this model

16. For versions of the supermultiplier model that formally incorporate the long-run adjustments of the size of the labor supply to the growth of employment opportunities, see Fazzari et al. (2018), Palley (2019), and Serrano (2019).

17. According to Blinder (who was vice chairman of the Federal Reserve), 'a negatively sloped IS curve is central to the Federal Reserve's thinking about how monetary policy works' (Blinder 1997 p. 240). But he notices that 'historical observations and at least some empirical research support the notion that higher real interest rates lead to lower spending ... . I suspect that the slope of the IS curve may have more to do with homebuilding and consumer durables (especially automobiles) than with business investment' (ibid., p. 240). Fair (2018) also argues that monetary policy affects the economy through autonomous consumption and residential investment. 18. On the other hand, leveraged bubbles (Jordà et al. 2015) can enhance a credit boom and stimulate autonomous spending. 
does not allow us to speak of a unique natural (or neutral) full employment level of the real interest rate. The first reason is because, given an initial level of capacity output, $Y^{*}$, even if there is a level of the policy interest rate that can make aggregate demand equal to it, it could only lead the economy to full capacity but not full employment output, $Y^{n}$.

On the other hand, even if we redefined the term natural interest rate to mean only demand equal to capacity output, rather than full employment of labor, as stated by Aspromourgos (2007) using a similar Sraffian supermultiplier IS curve, such a "natural' rate would not be unique. Aspromourgos demonstrates that any level of the policy interest rate $r$ held by the central bank for a sufficiently long time will become 'natural' in this sense. A particular level of $r$ will determine a particular level of effective demand and, through the supermultiplier, capacity output will tend to adjust to it. But the same would happen with any other level of the interest rate chosen by the monetary authority.

But perhaps the main reason why it is not useful to speak of a natural (or neutral) interest rate is because, in this model, there is no inverse long-run relationship between consumption (and any other components of aggregate demand that do not generate capacity for the business sector) and productive investment, since business investment is induced and capacity output is endogenous. If starting from a zero output gap - say, the government cuts its expenditures and then the central bank quickly lowers the real interest rate so much that aggregate demand goes back to the initial level of capacity output - all that has happened is that one has just replaced lower public consumption with higher private consumption. In this case, aggregate investment will stay where it was and so will both actual and capacity saving. This is the reason why we should not call the interest rate that makes demand and output equal to some initially given level of capacity output a natural rate of interest, since interest now does not represent the price of the choice between present and future consumption. There is no crowding-out effect and the only change in the real interest rate must derive from a policy decision by the central bank. The interest rate and financial wedge elements are purely distributive, instead of allocative variables.

And when we extend the analysis to a longer period in which business investment can change, a permanent decrease in the policy real interest rate (or a decrease in the financial wedge variables) will increase consumption and then investment as the actual degree of capacity utilization and expected demand changes, and will stimulate business investment via flexible accelerator effects.

It is then interesting to show, for the sake of comparison with the New Consensus model and its amendments, what happens to the relationship between the interest rate, investment, and full capacity (not full employment) saving, as capacity adjusts to demand via the supermultipler. Let us look first at the effects of a once-and-for-all increase in autonomous consumption as whole, at given levels of the interest rate and financial wedge variables. If initial capacity output and investment are taken as given, an increase in autonomous consumption will certainly reduce to the same extent the level of capacity saving $S^{*}$ (from point 1 to point 2 in Figure 4a below) as:

$$
S^{*}=(1-c)(1-t) Y^{*}-A-G
$$

But since in the Sraffian supermultiplier, in the longer run, neither business investment nor capacity output are exogenous, the propensity to invest will tend to its required level $v(d+z)$ and the level of fully adjusted capacity output will tend to the level 
described in equation (10). Replacing for the endogenous level of capacity output in the capacity saving equation above (putting equation (11) into (12)), we get:

$$
S^{*}=\frac{v(d+z)}{1-\left(1-v\left(r+f_{i}\right)(1-t)\right)-v(d+z)}\left(A_{0}-\alpha\left(r+f_{a}\right)+G\right) .
$$

From equation (13) we can easily see that the longer-run effect of an increase in the level of autonomous consumption is an increase in induced investment and also an increase, rather than a decrease, in capacity saving (as the economy will shift from point 2 to point 3 in Figure 4b). After all, potential or capacity saving is, in fact, merely another name for the size of the productive capacity of the capital goods sector of the economy that tends to adjust itself to the trend level of induced investment.

But in the same equation we can also see that the same is true for an increase in the rate of growth of autonomous $z$ which will also increase the level of capacity saving. Moreover, while it is true that a permanently higher rate of growth of the economy will require a higher investment share, this will happen as a result of a higher rate of growth of autonomous demand, inducing investment through the supermultiplier to grow for a while faster than the rate of growth of total (including autonomous) consumption and other expenditures that do not create capacity for the business sector (Serrano and Freitas 2017).

While business investment here is not a direct function of the rate of interest (the investment function appears as a vertical line in Figures $4 \mathrm{a}$ and $4 \mathrm{~b}$ ), persistently lower levels of the interest rate and financial wedge variables also have the effect of increasing both induced investment and capacity saving. All these results show that there is no longer-run trade-off between consumption and investment. Keynes argued that it was the level of output and income that adjusted actual saving to investment instead of the rate of interest adjusting investment to full employment saving. Here we see that, as capacity adjusts to demand via the supermultiplier, capacity saving ultimately adjusts to investment through changes in capacity output, and investment follows the trend of consumption or more generally expenditures that do not create capacity for the business sector (which Garegnani 1962 called 'final demand').

\section{CONCLUDING REMARKS: THE SRAFFIAN SUPERMULTIPLIER AND THE STYLIZED FACTS}

We can now briefly indicate (a proper discussion would require another whole paper) how in principle our simple Sraffian supermultiplier model of this type could help us to make sense of some of the stylized facts of the recent stagnation tendencies in adavanced countries as a case of policy-constrained growth. Basically, the growth rate of autonomous demand has slowed down due to the financial after-effects of the global financial crisis on residential investment and autonomous consumption. Lower policy interest rates have not helped much, in part because of the increase of the financial wedge, $f_{a}$, in the relevant interest rates. ${ }^{19}$ On the other hand, the multiplier effects seem to have weakened because of a long-run trend towards a falling wage share.

19. There is some evidence that a crisis after a housing boom and bubble financed by a large expansion of credit tends to be followed by slower recoveries (Jordà et al. 2015; Mian and Sufi 2015). 


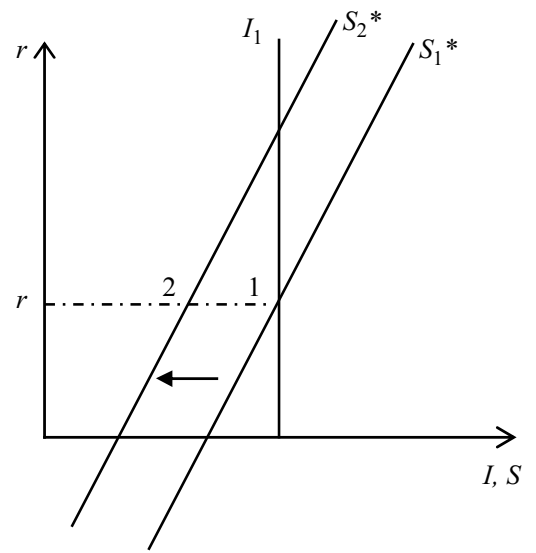

(a) With given capacity output

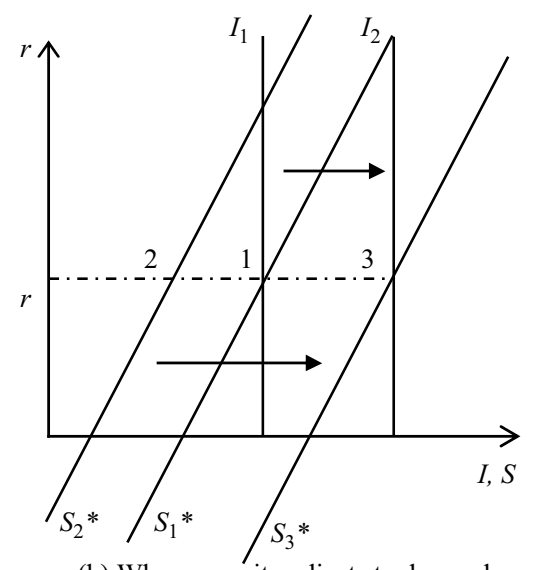

(b) When capacity adjusts to demand

Figure 4 Effect on an increase in autonomous demand on capacity saving

And the failure of the wage share to recover more recently, even with very low policy interest rates, could perhaps in part be related to compensating increases in the financial wedge for firms, $f_{i}{ }^{20}$

On top of that, and perhaps more importantly, we must consider the marked slowdown of the rate of growth of government spending and social transfers that has been a very important factor is slowing down the growth of autonomous demand, and, through the supermulitplier, the rate of growth of the economy in the long run in the advanced economies (Cynamon and Fazzari 2017 and Fair 2018 for the US case).

There is also plenty of evidence of potential output hysteresis in the mainstream literature. For Summers (2015, p. 63) this 'inverse of Say's Law ... lack of demand creates lack of supply potential' is demonstrated by showing that estimated full employment output is being reduced each year after the 2008 crisis in pace with current output (Summers 2016). ${ }^{21}$ Girardi et al. (2017) calls to attention that if this hysteresis mechanism is valid for recessions, the same can be applied to expansions, since autonomous spending increases have been shown to have persistent positive effects in the level of output in the long run. So, if for Ball (2014, p. 159) 'a better understanding of hysteresis mechanisms is a high priority for research,' the Sraffian supermultiplier model seems, if anything, much more compatible with the observed empirical results than the recent amendments of the New Consensus model. ${ }^{22}$

20. This could be part of the explanation for the behavior of the wage share. But we believe that the main part of the recent fall in the wage share is probably related to substantial increases in urban land rents and a rise of persistent above-normal (non-competitive) profits in many firms and sectors, which will not be discussed here.

21. More evidence on output hysteresis can be found in Ball (2014) and Blanchard et al. (2015).

22. Furman (2016) introduces a simple accelerator model of business fixed investment and so explains why aggregate demand shocks (like expansionary fiscal policy) can crowd-in with fixed business investment. 


\section{REFERENCES}

Aspromourgos, T. (2007), 'Interest as an artefact of self-validating central bank beliefs,' Metroeconomica, 58(4), 514-535.

Ball, L. (2014), 'Long-term damage from the Great Recession in OECD countries,' European Journal of Economics and Economic Policies: Intervention, 11(2), 149-160.

Bernanke, B. (2015), 'Why are interest rates so low,' Ben Bernanke's Blog.

Blanchard, O. (2016), 'How to teach intermediate macroeconomics after the crisis?' Peterson Institute For International Economics Blog, 2 June.

Blanchard, O. (2018), 'On the future of macroeconomic models,' Oxford Review of Economic Policy, 34(1-2), 43-54.

Blanchard, O., E. Cerutti, and L. Summers (2015), 'Inflation and activity: two explorations and their monetary policy implications,' NBER Working Paper No 21726.

Blinder, A. (1997), 'Is there a core of practical macroeconomics that we should all believe?' The American Economic Review, 87(2), 240-243.

Borio, C. (2017), 'Secular stagnation or financial cycle drag?' Business Economics, 52(2), 87-98.

Caballero, R., E. Farhi, and P. Gourinchas (2017), 'Rents, technical change, and risk premia accounting for secular trends in interest rates, returns on capital, earning yields, and factor shares,' American Economic Review, 107(5), 614-620.

Carlin, W. and D. Soskice (2005), 'The 3-equation New Keynesian model: a graphical exposition,' Contributions in Macroeconomics, 5(1), 1-36.

Cynamon, B. and S. Fazzari (2017), 'Secular demand stagnation in the 21st century US economy,' Mimeo, Preliminary Draft Prepared for INET Secular Stagnation Conference, New York, December.

Di Bucchianico, S. (2018), 'A note on Krugman's liquidity trap,' UMass Amherst Economics Working Papers 2018-17, University of Massachusetts Amherst, Department of Economics.

Di Bucchianico, S. (2019), 'A critical analysis of the secular stagnation theory,' Departmental Working Papers of Economics, University 'Roma Tre,' No 0245.

Fair, R. (2018), 'Explaining the slow US recovery: 2010-2017,' Business Economics, 53(4), 184-194.

Fazzari, S., P. Ferri, and A. Variato (2018), 'Demand-led growth and accommodating supply,' FMM Working Paper No 15.

Freitas, F. and F. Serrano (2015), 'Growth rate and level effects, the stability of the adjustment of capacity to demand, and the Sraffian supermultiplier,' Review of Political Economy, 27(3), $258-281$.

Furman, J. (2016), 'The new view of fiscal policy and its application,' Council of Economic Advisors, Conference Remarks, 5 October.

Garegnani, P. (1962 [2015]), 'The problem of effective demand in Italian economic development: on the factors that determine the volume of investment,' Review of Political Economy, 27, 111-133.

Garegnani, P. (1979), 'Notes on consumption, investment and effective demand, Part II: monetary analysis,' Cambridge Journal of Economics, 3(1), 63-82.

Garegnani, P. (1990), 'Sraffa: classical versus marginalist analysis,' in K. Bharadwaj and B. Schefold (eds), Essays on Piero Sraffa: Critical Perspectives on the Revival of Classical Theory, London: Unwin-Hyman, pp. 112-140.

Garrido Moreira, V. and F. Serrano (2018), 'A Hipótese De Estagnação Secular Nas Teorias Do Crescimento Econômico: Um Labirinto De Inconsistências Teóricas,' Working Paper, IE-UFRJ No 15.

Girardi, D., W. Meloni, and A. Stirati (2017), 'Persistent effects of autonomous demand expansions,' Mimeo, Preliminary Draft Prepared for the INET Secular Stagnation Conference, New York, December.

Hall, R. (2013), 'The routes into and out of the zero lower bound,' Paper Presented at Jackson Hole Economic Policy Symposium 2013. 
Jordà, Ò., M. Schularick, and A.M. Taylor (2015), 'Leveraged bubbles,' Journal of Monetary Economics, 76, S1-S20.

Krugman, P. (2015), 'Liquidity traps, temporary and permanent: the conscience of a liberal,' 2 November, available at: https://krugman.blogs.nytimes.com/.

Levrero, E.S. (2019), 'Estimates of the natural rate of interest and the stance of monetary policies: a critical assessment,' Institute for New Economic Thinking Working Paper Series No 88.

Mian, A. and A. Sufi (2015), House of Debt: How They (and You) Caused the Great Recession, and How We Can Prevent It from Happening Again, Chicago: University of Chicago Press.

Pagano, P. and M. Sbracia (2014), 'The secular stagnation hypothesis: a review of the debate and some insights,' Bank of Italy Occasional Paper, No 231.

Palley, T. (2016), 'Why ZLB economics and negative interest rate policy (NIRP) are wrong: a theoretical critique,' IMK Working Paper.

Palley, T. (2018), 'Recovering Keynesian Phillips curve theory: hysteresis of ideas and the natural rate of unemployment,' Review of Keynesian Economics, 6(4), 473-492.

Palley, T. (2019), 'The economics of the super-multiplier: a comprehensive treatment with labor markets,' Metroeconomica, 70(2), 325-340.

Pariboni, R. (2016), 'Household consumer debt, endogenous money and growth: a supermultiplierbased analysis,' PSL Quarterly Review, 69(278), 211-233.

Petri, F. (2004), General Equilibrium, Capital and Macroeconomics: A Key to Recent Controversies in Equilibrium Theory, Cheltenham, UK and Northampton, MA: Edward Elgar Publishing.

Petri, F. (2013), 'The inevitable dependence of investment on expected demand: implications for neoclassical macroeconomics,' in E.S. Levrero, A. Palumbo, and A. Stirati (eds), Sraffa and the Reconstruction of Economic Theory, vol. 2: Aggregate Demand, Policy Analysis and Growth, Basingstoke, UK: Palgrave Macmillan, pp. 44-67.

Petri, F. (2015), 'Neglected implications of neoclassical capital-labour substitution for investment theory: another criticism of Say's law,' Review of Political Economy, 27(3), 308-340.

Pivetti, M. (1991), An Essay on Money and Distribution, London: Macmillan.

Serrano, F. (1995), 'Long period effective demand and the Sraffian supermultiplier,' Contributions to Political Economy, 14(1), 67-90.

Serrano, F. (2019), 'Mind the gaps: the conflict augmented Phillips curve and the Sraffian supermultiplier,' Working Paper, IE-UFRJ No 11.

Serrano, F. and F. Freitas (2017), 'The Sraffian supermultiplier as an alternative closure for heterodox growth theory,' European Journal of Economics and Economic Policies: Intervention, 14(1), 70-91.

Serrano, F., F. Freitas, and G. Bhering (2019), 'The trouble with Harrod: the fundamental instability of the warranted rate in the light of the Sraffian supermultiplier,' Metroeconomica, 70(2), 263-287.

Solow, R. (1997), 'Is there a core of usable macroeconomics we should all believe in?' The American Economic Review, 87(2), 230-232.

Stirati, A. and W. Meloni (2018), 'A short story of the Phillips curve: from Phillips to Friedman ... and back?' Review of Keynesian Economics, 6(4), 493-516.

Summa, R. and J. Braga (2019), 'The (conflict augmented) Phillips curve is "alive and well", Working Paper, IE-UFRJ, No 3.

Summers, L. (2015), 'Demand side secular stagnation,' The American Economic Review, 105(5), $60-65$.

Summers, L. (2016), 'Secular stagnation and monetary policy,' Federal Reserve Bank of St. Louis Review, 98(2), 93-110.

Taylor, J. (2000), 'Teaching modern macroeconomics at the principles level,' American Economic Review, 90(2), 90-94.

Yellen, J. (2016), 'Macroeconomic research after the crisis,' Speech, 60th Annual Economic Conference Federal Reserve Bank of Boston, 14 October. 